Indonesian Journal of Global Health Research

Volume 3 Number 1, February 2021, pp. 73 - 80

e-ISSN 2715-1972; p-ISSN 2714-9749

http://jurnal.globalhealthsciencegroup.com/index.php/IJGHR

\title{
STRESS MANAGEMENT ON SENIOR HIGH SCHOOL STUDENTS IN SEMARANG
}

\author{
Dwi Heppy Rochmawati ${ }^{1 *}$, Wigyo Susanto ${ }^{1}$, Hetty Catur Ellyawati ${ }^{2}$ \\ ${ }^{1}$ Faculty of Nursing, Sultan Agung Islamic University Semarang, Jl. Kaligawe Raya KM 4, Terboyo \\ KulonGenuk, Kota Semarang, Jawa Tengah. Indonesia 50112 \\ ${ }^{2}$ Faculty of Information and Communication Technology, University of Semarang, Jl. Soekarno Hatta, Tlogosari \\ Kulon, Pedurungan, Kota Semarang, Jawa Tengah, Indonesia 59160 \\ *dwiheppy@unissula.ac.id
}

\begin{abstract}
Stress is a mental emotional disorder faced by a person due to pressure. Such pressure arises from the failure of individuals to fulfill their needs or wants. The pressure felt by someone can come from within or from outside of themselves. Individuals who experience stress need proper management, so as not to cause further harmful effects. One of the stress management method is by providing 5-finger technique therapy. The purpose of this study was to determine the effect of the 5-finger technique on the high school students' stress level in Semarang. This study used a Quasi-Experiment Pretest-Posttest design without a control group. The instrument used was a 5-finger technique therapy worksheet, while the stress level was measured using the DASS-42 (Depression Anxiety Stress Scale). Approximately 90 respondents were chosen through simple random sampling and met the including criteria. The data analysis was conducted by using Mann Whitney statistical test, obtaining p-value $<0.05(0.00)$ was obtained with a decrease in the respondents' stress level. The results showed that the 5-finger technique reduced the respondents' stress level.
\end{abstract}

Keywords: 5-finger technique; pretest and posttest without control group; quasi-experiment; stress

\begin{tabular}{|c|c|}
\hline $\begin{array}{c}\text { First Received } \\
12 \text { December } 2020\end{array}$ & $\begin{array}{c}\text { Accepted } \\
28 \text { December } 2020\end{array}$ \\
\hline $\begin{array}{c}\text { Final Proof Received } \\
\text { 03 January } 2021\end{array}$ & $\begin{array}{c}\text { Published } \\
11 \text { February } 2021\end{array}$ \\
\hline $\begin{array}{l}\text { How to cite (in APA style) } \\
\text { Rochmawati, D. H., Susanto, W., \& Ellyawati, H. (2021). Stress } \\
\text { Students in Semarang. Indonesian Journal of Global } \\
\text { https://doi.org/10.37287/ijghr.v3i1.373 }\end{array}$ & $\begin{array}{l}\text { Management on Senior High School } \\
\text { Health Research, 3(1), } \quad 73-80 .\end{array}$ \\
\hline
\end{tabular}

\section{INTRODUCTION}

Stress is a condition formed by a combination of several factors that significantly affect individual's behavior and interpersonal relationships. The formation process of individual's stress is affected by his environment. A person's physical and emotional status, lifestyle, and financial status determine the stress level. In today's society, stress-related illnesses increase day by day, so people and institutions face important problems (Boyaci, 2014).

Academic stress is a condition in which individuals, in this case are adolescents, experience academic pressure in the form of perceptual pressure and assessment of academic stressors related to science and education. Academic stressors experienced by these adolescent students can be in the form of internal and external stressors that can have a positive and negative impact on adolescent students who experience them. The stress problem can be overcome by several ways, either pharmacological or using drugs and non-pharmacological, for example deep breathe relaxation and five-finger hypnosis. According to Davis (2000), relaxation/inhale therapy can reduce stress in the right way. In addition, relaxation therapy is very important for mental and physical health. Inhalation during relaxation therapy stimulates the emergence of natural nitric oxide which can function to make a person calmer. 
Another relaxation technique that can be given is the five-finger hypnosis relaxation technique is the 5-finger technique. According to Mahoney (2007), rewritten by Hastuti (2015), five-finger hypnosis is a self-hypnosis technique that can provide a high relaxing effect, thereby reducing or decreasing the level of tension and stress in a person's mind. One of the studies on the prevalence of stress was conducted on 369 medical students in Malaysia obtaining a prevalence of $41.9 \%$ of students experienced stress (Augesti, 2015). According to Kholidah (2012) in his research, $45.3 \%$ of students experienced stress while working on their thesis. In another study conducted by Wulandari (2012) on 334 respondents who were and were not working on their thesis, it was found that $46.48 \%$ of the students who were in thesis experienced stress.

Several studies suggest the benefits of five-finger hypnosis. Research was conducted by Noorkasiani (2014) entitled "The effectiveness of five-finger hypnosis therapy to reduce anxiety levels in hypertensive patients". In patients with high blood pressure who experienced anxiety in East Jakarta, resulted that five-finger hypnosis can reduce the anxiety level of patients with p-value of $\alpha$ 0.019. Similar research was conducted by Sonia (2014) entitled "The Effect of Five-Finger Exercises on Anxiety in Preoperative Laparotomy Patients at Irna Surgical Hospital DR. M Djamil Padang". The results obtained also show that five-finger hypnosis can reduce anxiety.

A preliminary study conducted by researchers at a high school in Semarang showed that, among the 15 students, 14 of them said that they were stressed (ranging from mild, moderate, severe and very severe). Only 1 student did not experience stress. The purpose of this study was to determine the effect of 5-finger technique on stress experienced by students.

\section{METHOD}

This research was conducted quantitatively through a Quasi-Experimental Pretest-Posttest design without a control group. The population in this study were all high school students, amounting to 113 students. The sample in this study consisted of 90 students who met the inclusion and exclusion criteria. The sampling technique used this study was simple random sampling. The research instrument used was stress questionnaire proposed by Lovibond (1995), namely the DASS-42 (Depression Anxiety Stress Scale) containing 42 statement items in which 14 statements are specified for stress as well as a 5-finger technique therapy work module. Researchers did not test the validity and reliability of the questionnaire used because it has been a standard. Analysis was done by using univariate and bivariate. Bivariate analysis was performed through Mann Whitney test. Therapeutic method of 5-finger technique was carried out for \pm 15 minutes with concentration and relaxation. The technique was done initially by touching the thumb with the index finger and reminiscing about when you were healthy; the second is touching the thumb with the middle finger and reminisces about getting compliments and successes; the third is touching the thumb with the ring finger and reminisces the faces of the cherished people and lastly touches the thumb with the little finger and reminisces about the most beautiful place ever visited. 


\section{RESULTS}

Table 1.

Characteristics of Respondents by Gender $(n=90)$

\begin{tabular}{ccc}
\hline Gender & f & $\%$ \\
\hline Male & 34 & 37.8 \\
\hline Female & 56 & 62.2 \\
\hline
\end{tabular}

The analysis results based on table 1 show that the majority of respondents are female by 56 respondents $(62.2 \%)$, while the remaining 34 respondents $(37.8 \%)$ are male.

Table 2

Characteristics of Respondents by Age $(n=90)$

\begin{tabular}{lll}
\hline Age & f & $\%$ \\
\hline 16 & 30 & 33.3 \\
\hline 17 & 10 & 11.1 \\
\hline 18 & 50 & 55.6 \\
\hline
\end{tabular}

The research results concerning the respondents' age obtained that most of the respondents were at the age of 18 years old by 50 respondents $(55.6 \%)$, while the smallest age range was 17 years old by 10 respondents $(11.1 \%)$.

Table 3

Characteristics of Respondents by Class $(\mathrm{n}=90)$

\begin{tabular}{ccc}
\hline Class & f & $\%$ \\
\hline X & 54 & 60 \\
\hline XI & 36 & 40 \\
\hline
\end{tabular}

Based on table 3, the results show that the respondents are dominated by class $\mathrm{X}$ by 54 respondents $(60 \%)$ and class XI by only 36 respondents $(40 \%)$.

Table 4

Characteristics of Respondents based on Level of Stress before and after Therapy $(n=90)$

\begin{tabular}{ccccc}
\hline Stress Level & \multicolumn{2}{c}{ Pre test } & \multicolumn{3}{c}{ Post test } \\
\cline { 2 - 5 } & $\mathrm{f}$ & $\%$ & $\mathrm{f}$ & $\%$ \\
\hline Normal & 10 & 11.1 & 15 & 16.7 \\
\hline Mild & 15 & 16.7 & 25 & 27.7 \\
\hline Moderate & 45 & 50 & 50 & 55.6 \\
\hline Severe & 12 & 13.3 & 0 & 0 \\
\hline Very Severe & 8 & 8.9 & 0 & 0 \\
\hline
\end{tabular}

Table 4 shows the results that the respondents' stress level before therapy was mostly at the moderate stress level by 45 respondents $(50 \%)$, while 8 respondents $(8.9 \%)$ were at severe stress level. Furthermore, after the 5-finger therapy was given, there were 50 respondents $(55.6 \%)$ who were at moderate stress level, while 15 respondents $(16.7 \%)$ did not experience stress. 
Table 5

\begin{tabular}{cccc}
\multicolumn{4}{c}{ Bivariate Analysis of Stress Level $(\mathrm{n}=90)$} \\
\cline { 1 - 3 } Stress Level & Mean & Median & P value \\
\hline Pre test & 20.3 & 20 & 0.000 \\
\hline Post Test & 16.3 & 19 & \\
\hline
\end{tabular}

Table 5 shows that the analysis results using the Mann Whitney test obtained that the average stress level score before participating the 5-finger technique therapy was 20.3, while after participating in the therapy became 16.3 with a difference of positive 4 . It means that there was a decrease in stress levels after participating in the 5-finger technique therapy with an average decrease of 4 . In the table above, the p-value was 0.000 , meaning that there was a significant difference between the average stress level before and after the 5 -finger technique therapy. Thus, it can be concluded that 5-finger technique significantly decreased the stress levels.

\section{DISCUSSION}

\section{Gender}

The research results showed that most of the respondents are female by 56 respondents (62.2\%). This research is in accordance with the research conducted by Affandi (2017) entitled the Effect of Deep Breath and 5-Finger Technique on Students' Stress, which stated that women are more prone to experience stress than men. Gender also determines the occurrence of stress. According to Brizendin (2007), there are differences in responses between men and women when experiencing problems/conflicts. The structure of the female brain has a negative alertness to conflict and stress. When women experience conflict, negative hormones will be triggered higher than usual, causing stress, anxiety, and fear. Women will feel more stressed when they experience conflict. Women feel that they need more protection. Meanwhile, men generally enjoy the existence of conflict and competition, and even think that conflict can provide a positive boost.

\section{Age}

Most of the research respondents were 18 years old with a total of 50 respondents $(55.6 \%)$. This age belongs to adolescence group which is the age of transition or change from the childhood stage to the adult stage, starting from 12 years old to 20 years old (Budiargo, 2015). Many changes occur during adolescence, including physical, biological, psychological, attitudes, behavior and thought patterns changes. Teenagers want to appear and be the same as other people or role models that they are proud of.

The desire to be like other people and the same as other people, makes teenagers do many things to make it happen. When they cannot make it happen, stress will occur. Stress occurs because of an imbalance between needs, hopes and desires with accepted reality. The immature age of adolescents greatly determines adolescents in their attitude toward their condition. This is also what causes stress.

\section{Class}

The results of the study obtained that most of the respondents were at class $\mathrm{X}$ by 54 respondents (60\%). Respondents who were involved in this study were only class X and class XI, while class XII was not included because they were preparing for the final school exams. Class XII students experience more stress due to exam preparation. So that if included there will be bias in the results of the study. 
Class X and XI students are transitioning from junior high school to high school, they still have to adapt to different assignments and learning from the previous class. Moreover, the current learning system (COVID-19 pandemic) was carried out from each home (study from home). This is one of the causes of the stress they experience.

\section{Stress before and after Therapy}

The stress level of the majority of respondents before participating in the 5-finger technique was moderate stress $(50 \%)$, while after participating in the 5-finger technique, the majority still experienced moderate stress $(55.6 \%)$. There was an increase in the number of respondents who experienced moderate stress. Likewise, the level of normal and light stress before therapy, from the initial number of 10 respondents (11.1\%) and 15 respondents (16.7\%), to 15 respondents $(16.7 \%)$ and 25 respondents $(27.7 \%)$ on the measurement after giving 5 -finger technique therapy. However, there was a significant decrease in respondents who experienced severe and very severe stress before the therapy, namely 12 respondents $(13.3 \%)$ and 8 respondents $(8.9 \%)$ who were not experienced at all by respondents in the post-therapy measurement.

\section{The effect of therapy on stress}

The analysis conducted by using Mann-Whitney test obtained a p-value of 0.000 , meaning that there was a significant difference between the average stress level before and after the 5finger technique therapy. Thus, it can be concluded that there was a significant effect of 5finger technique therapy on reducing stress levels.

In accordance with Affandi's research (2017), 5-finger hypnosis was proven as a very effective method to reduce stress levels. Anxiety and stress can be overcome with relaxation techniques, distraction, spiritual activities and hypnotherapy (Keliat, 2015). There are several types of hypnosis that can be done, one of which is hypnosis using the 5-finger technique. Individuals or clients are helped to change their perceptions of anxiety, stress, tension and fear by accepting suggestions on the threshold of unconsciousness or in a relaxed state by moving their fingers according to orders (Long, 2010).

By entering the client's subconscious mind with the media of fingers, negative patterns that have been done by the client can be corrected and reprogrammed by providing new insights that can provide long-term comfort and calm for the client. The 5-finger technique is a therapy that uses fingers as a medium for distraction (Axelrad, 2009). Five-finger hypnosis is a technique of distracting someone's thoughts by touching the fingers while imagining things that are fun or like (Keliat, 2015).

The stress conditions experienced by students could not be identified, because there was no complete interview session with all respondents. However, from the opportunities that exist, the researchers had time to interact online with respondents through whatsapp conversations. The results showed that the stress experienced was caused by many factors, including the condition of Covid-19 pandemic which could not be ascertained when it would end, the online learning process which sometimes caused delays in following and uncertainty about the future due to conditions. This is experienced by some respondents, researchers cannot confirm that all respondents experience the same thing. Many internal and external factors cause stress which may be experienced by respondents.

However, stress is a condition that requires special handling. Non-pharmacological management is highly recommended because it does not affect the body's organs and can be 
done independently anywhere and anytime in a comfortable place such as by giving therapy as has been done. The results of this study proved that there was a decrease in stress level after giving the 5-finger technique. This therapy provides a feeling of relaxation or comfort so that students feel better about themselves than before.

\section{CONCLUSION}

In terms of the respondents' characteristics, most of them are 18 years old (55.6\%), female $(62.2 \%)$ and students at class $X(60 \%)$. The average score of stress level before the 5-finger technique therapy is 20.3 with most of the respondents experiencing moderate stress $(50 \%)$, while the average score of stress level after 5 finger technique therapy is 16.3 with most of them experiencing moderate stress $(55.6 \%)$. Through the Mann Whitney test, the p-value obtained is $0.000(<0.05)$, which means that there is a significant effect of 5 -finger technique therapy on reducing stress levels.

\section{ACKNOWLEDGEMENT}

The Research Team would like to thank LPPM (Institute for Research and Community Service) of Universitas Sultan Agung Islamic for their support, funding and cooperation so that this research activities can be carried out well

\section{REFERENCES}

Affandi, I. M. (2017). Pengaruh Terapi Relaksasi Napas Dalam dan Hipnosis Lima Jari terhadap Tingkat Stres Mahasiswa Program Studi Ilmu Keperawatan Universitas Aisyiyah Yogyakarta. http://digilib.unisayogya.ac.id/id/eprint/2540

Al Aqsari. (2005). Kunci Sukses Membangun Rasa Percaya Diri. Jakarta. Cendikia.

Astuti, R.T., Amin, M.K., Purborini, N. (2020). Efektifitas Metode Hipnotis Lima Jari (HP Majar) terhadap Tingkat Stres Akademik Remaja di SMK Muhammadiyah 2 Kabupaten Magelang. http://journal.ummgl.ac.id/index.php/nursing/article/view/1110

Augesti, G., Lisiswanti, R., Saputra, O., Nisa, K. (2015). Differences in Stress Level between First Year and Last. J Majority, 4, 50-56. https://juke.kedokteran.unila.ac.id/index.php/majority/article/view/578

Axelrad, M. D., Brown, D., Wain, H. (2009). Kaplan \& Sadock's Comprehensive Textbook of Psychiatry Ninth edition, Hypnosis

Boyaci, K., Sensoy, F., Beydag, K. D., \& Kiyak, M. (2014). Stress and Stress Management in Health Institutions. Procedia - Social and Behavioral Sciences, 152, 470-475. https://doi.org/10.1016/j.sbspro.2014.09.233

Budiargo, D. (2015). Berkomunikasi Ala Net Generation. Jakarta: PT Elex Media Komputindo

Cormier, W.H. \& Cormier S.L. (1985). Interviewing strategies for helpee: fundamental skill and behavior interventions. Second edition. California. Brokd. Cole. Pub.co.

Cornier, W.H \& Cornier S.L. (1985). Interviewing strategies for help: fundamental skill and behavior interventions. Second edition. California. Brokd.

Council, T. C., Gilchrest. (2004). Manajemen Stres. Alih Bahasa 
Davis, M., Robbins, Elizabeth, Eshelman, and McKay, M. (2000). The Relaxation \& Stress Reduction Workbook. 5th edition. Oakland, CA: New Harbinger Publications.

Ellis A. (1984). Rational emotive therapy and cognitive behavior therapy. New York: Springer.

Georgia Southern University. (2010). Suggestions for reducing stress. Counseling Services. http : //students. georgiasouthern. edu/counseling/ workshop/ stress/suggestions.html

Goldfried, M.R. \& Decentecco, E.T. \& Wienberg, L. (1979). Systematic rational restructuring as self control technique. Behavior Therapy,5,247-254.

Hamid, A.Y., Keliat, B.A. (1995). Panduan Relaksasi dan Reduksi Stress. edisi ketiga. Jakarta

Hart, A. (2010). Stress Management for Students. EzineArticles Submission - Submit Your Best Quality Original Articles For Massive Exposure, Ezine Publishers Get 25 Free Article Reprints. http://ezinearticles.com

Keliat, B.A. (2011). Standar Asuhan Keperawatan Management Stress. Jakarta. Universitas Indonesia.

Keliat, B. A. (2015). Standart Asuhan Keperawatan Jiwa (gangguan, resiko dan sehat). Keperawatan Jiwa IX DEPOK 2015. Prodi Ners Spesialis Keperawatan Jiwa. Fakultas Keperawatan UI.

Kelly, Sam, Brooke, Danielle, 2010, Progressive Muscle Relaxation, Harvard University

Kholidah, E. N., \& Alsa, A. (2012). Berpikir Positif untuk Menurunkan Stres Psikologis. Jurnal Psikologi, 39, 67-75.

Kristyaningsih, F., Keliat, B. A. dan Daulima, N. H. C. (2009). Pengaruh Terapi Kognitif terhadap Perubahan Harga Diri dan Kondisi Depresi Pasien Gagal Ginjal Kronik di Ruang Haemodialisa RSUP Fatmawati Jakarta.

Long, B. C. (2010). Perawatan Medical Bedah. Bandung: Yayasan BTPK Padjajaran. National Safety

Lovibond, P. F, \& Lovibond, S. H. (1995). The structure of negative emotional states: Comparison of the Depression Anxiety Stress Scales (DASS) with the Beck Depression and Anxiety Inventories. Behaviour Research and Therapy, 33, 335-342

Malgaj, Luka. (2010). Top 7 Stress Management Tips For Students. EzineArticles Submission - Submit Your Best Quality Original Articles For Massive Exposure, Ezine Publishers Get 25 Free Article Reprints. http ://ezinearticles. com

Mayo Clinic Staff. (2010). Stress Management. Mayo Clinic Medical Information and Tools for Healthy Living - MayoClinic.com. http ://www. mayoclinic. com/health

Morist and Kanitz. Stress and cognitive: handbook of life stress. Cognition and health Manchester: John willey \& Sons. Ltd. 
Noorkasiani, E. B. E. D. (2014). Efektivitas Terapi Hipnotis Lima Jari Untuk Menurunkan Tingkat Ansietas Pasien Hipertensi. Jurnal Keperawatan, 2(3), 24-33

Rossman, M.L. (2001). Guided Imagery for Self-Healing. Tiburon, CA: HJ Kramer.

Sonia, G. (2014). Pengaruh Latihan Lima Jari Terhadap Kecemasan Pada Pasien Pre Operasi Laparatomi Di Irna Bedah RSUP. Dr. M. Djamil Padang (Doctoral dissertation, andalas university).

Smith, Melinda, Ellen Jaffe-Gill, and Robert Segal. (2010). Stress Management: How to Reduce, Prevent, and Cope with Stress. Helpguide.org: Understand, Prevent and Resolve Life's Challenges. Helpguide.org, http ://helpguide. org/mental

Stuart, G.W. (2009). Principles and Practices of Psychiatric Nursing. $9^{\text {th }}$ ed. St. Louis : Mosby Elsevier.

Stuart, G.W., \& Laraia M.T (2005). Principles and practice of psychiatric nursing, $\left(8^{\text {th }}\right.$ ed), St. Louis: Mosby.

Terrell, C.J. (2010). Progressive Muscle Relaxation, Psychological Studies Institute

Thantaway. (2005). Kamus Istilah Bimbingan dan Konseling. Jakarta.

Townsend, Mary C. (2009). Psychiatric Mental Health Nursing: Concepts of Care in Evidence-Based Practice. $6^{\text {th }}$ ed. Philadelphia: F.A Davis Company.

Varcarolis, E.M, Carson, V. B, Shoemaker, N. C. (2006). Foundation of psychiatric mental health nursing. $6^{\text {th }}$ ed. St. Louis: WB Saunders Company.

Widarso, Wishnubroto. (2005). Sukses Membangun Rasa Percaya Diri. Jakarta. Grasindo. http: //www. e-psikologi. comG; /345 strategi-membangun-rasa-percaya-diri.html (Diakses tanggal 15 September 2011). 